\title{
Amino Acid Composition of Macrobrachium vollenhovenii and Callinectes amnicola from Badagry Creek, Lagos, Nigeria
}

\author{
*Corresponding Author \\ Abayomi Jimoh

\section{Article History} \\ Received: 20.11.2019 \\ Accepted: 27.11 .2019 \\ Published: 09.12.2019
}

Abayomi Jimoh*, Edwin Clarke and Anuoluwapo Akanbi

Department of Fisheries, Lagos State University, Ojo

\begin{abstract}
Amino acid composition of the body parts of Macrobrachium vollenhovenii and Callinectes amnicola collected from Badagry creek were assessed and determined. Fifteen and twelve samples of $M$. vollenhovenii and $C$. amnicola respectively were used in the study. The weight of the prawns ranged from $4.09 \mathrm{~g}-17.50 \mathrm{~g}$ while the crab ranged from $31.00 \mathrm{~g}-119.82 \mathrm{~g}$. The prawns were separated into three (3) different parts which are the whole prawn, flesh and exoskeleton while the crabs were limited to the whole $\mathrm{crab}$ and the flesh. Chemical analysis was carried out following the modified method AOAC method 982.30, while the data obtained were analyzed using SPSS version 20.0. Eighteen amino acids were reported made up of ten (10) essential amino acids (EAA) and eight non-essential amino acids (NEAA). The EAA were arginine, histidine, isoleucine, leucine, lysine, methionine, phenylalanine, threonine, tryptophan and valine, while the NEAA were glycine, alanine, proline, aspartate, glutamate, tyrosine and cystine. The ratio of EAA: NEAA in M. vollenhovenii and C. amnicola was 1.25. There were significant differences $(p=0.05)$ among the amino acids from the various parts analysed. Glutamate recorded the highest concentration while cystine recorded the lowest concentration in both crustaceans. Thus, these crustaceans probably play important roles in learning and sensitivity due to the concentration of glutamate which is a powerful excitatory neurotransmitter that is released by nerve cells in the brain. On the basis of nutrition and higher concentration of amino acids, M. vollenhoveni and C. amnicola are better sources of protein and can serves as substitutes for other proteinous food.
\end{abstract}

Keywords: Amino acids, Macrobrachium vollenhovenii, Callinectes amnicola, Badagry Creek.

\section{INTRODUCTION}

Freshwater prawns of the genus Macrobrachium are decapods crustaceans in the family Palaemonidae. The palaemonids and penaeids have been globally acknowledged because of their importance and possibility for recruitment into aquaculture. Macrobrachium species are found in most inland freshwaters area and constitute an important part of the artisanal fishery. In addition to its wide distribution, M. vollenhovenii is one of the largest Macrobrachium species known [1]. Crabs constitute an important species in the traditional shellfish culture system in coastal areas in Nigeria and have become increasingly popular by virtue of meat quality and large size. The swimming crab, Callinectes amnicola, is an important food item in coastal waters of West Africa. C. amnicola is abundant all year round especially in shallow shaded sub-tidal waters where it is caught in large quantities [2]. It constitutes a major source of protein in the diet of people in the coastal states of Nigeria.

Food and tissue proteins contain 20 different amino acids including essential and non-essential amino acids of nutritional importance. Shellfishes contain varying levels of high quality protein rich in all the valuable dietary essential amino acids. Amino acids are mainly obtained from proteins in diet therefore a sufficient quantity of dietary protein is required for growth, survival, development, reproduction and maintaining good health throughout life $[3,4]$.

Since amino acids have been reported to have a lot of biological importance, and prawns/crabs are regarded as good sources of proteins, this study was carried out to determine the amino acid composition of the African river prawn, Macrobrachium vollenhovenii and the crab, Callinectes amnicola from Badagry Creek, Lagos, Southwest Nigeria.

Copyright @ 2019: This is an open-access article distributed under the terms of the Creative Commons Attribution license which permits unrestricted use, distribution, and reproduction in any medium for non commercial use (NonCommercial, or CC-BY-NC) provided the original author and source are credited. 


\section{MateRIALS ANd METHOd \\ Collection and Transportation of Samples}

Fifteen (15) samples of the African river prawn (Macrobrachium vollenhovenii) and 12 samples of the crab (Callinectes amnicola) were used for this study, with weight range of $4.09 \mathrm{~g}-17.50 \mathrm{~g}$ (M. vollenhovenii) and $31.00 \mathrm{~g}-119.82 \mathrm{~g}$ (C. amnicola). The prawn and crab samples were purchased from fishmongers around the Badagry Creek, Lagos State, Nigeria. The samples were transported on ice to the Fisheries laboratory at the Lagos State University where the samples were prepared for analysis.

\section{Preparation of Sample for Analysis}

The prawn samples were separated into three (3) parts: whole prawn, flesh and exoskeleton while the crabs were separated into two (2) parts: whole crab and the flesh. The samples were oven dried to constant weight at $75^{\circ} \mathrm{C}$ (hot-air sterilizer GRX-9023A) for about 72 hours and the oven-dried samples were ground to fine powder, about $20 \mathrm{~g}$, for analysis. Thereafter, the powdered samples of the various parts of the prawn and crab samples were transported in sealed plastic bottles to the laboratory of the College of Medicine, University of Lagos for amino acid analysis of the samples.

\section{Analysis and Extraction of Amino Acids}

Extraction and instrumentation were carried out following the modified Association of Official Analytical Chemists method 982.30 [5]. The dried and pulverized sample was made to be free of water by ensuring constant weight for a period of time in the laboratory. The sample of $0.5 \mathrm{~g}$ was weighed into $250 \mathrm{ml}$ conical flask capacity. The sample was defatted by extracting the fat content of the sample with $30 \mathrm{ml}$ of the petroleum spirit three times with Soxhlet extractor that was equipped with thimble. Then the sample was hydrolyzed three times for complete hydrolysis to be achieved for the totality of amino acids recovery. The pulverized and defatted sample was soaked with $30 \mathrm{ml} 1 \mathrm{M}$ potassium hydroxide solution and was incubated for 48 hours at $110^{\circ} \mathrm{C}$ in hermetically closed borosilicate glass container. After the alkaline hydrolysis, the hydrolysate was neutralized to get pH in the range of 2.5 - 5.0 . The solution was purified by cation-exchange solid phase extraction. The amino acids in purified solution were derivatised with ethylchloroformate by the established mechanism.

\section{Statistical Analysis}

The results obtained from chemical analysis were tested using standard deviation and analysis of variance using SPSS version 20.0

\section{RESULTS AND DISCUSSION}

In this study, 18 amino acids (Table 1) were isolated from the various parts of Macrobrachium vollenhovenii and Callinectes amnicola; ten (10) were essential amino acids (EAA) while eight (8) were non-essential amino acids (NEAA). The EAA were arginine, histidine, isoleucine, leucine, lysine, methionine, phenylalanine, threonine, tryptophan and valine, while the NEAA were glycine, alanine, proline, aspartate, glutamate, tyrosine and cystine. Bhavan et al. [6] reported 18 amino acids, comprising 11 EAA and 7 NEAA, in M. rosenbergii from natural culture environments in India, while Tag El Din et al. [7] reported 16 (9 EAA and 7 NEAA) in M. rosenbergii and Penaeus semisulcatus. Thirteen amino acids made up of 8 EAA and 5 NEAA were isolated from M. vollenhovenii and Tympanotonus fuscatus from Benin River, Nigeria [8], while Abdel-Salam [9] reported 9 EAA and 7 NEAA in important crustaceans from Egyptian and Saudi Arabia coasts. For crabs, Sudhakar et al. [10] and Sankar and Yogamoorthi [11] reported 7 EAA, 7 NEAA and 7 EAA, 5 NEAA in Ocypode platytarsis and Portunis sanguinolentus respectively. The nutritive value of any animal is determined by the presence of EAAs [10]. However, recently, the concept of functional amino acids (FAAs) has been proposed. FAAs are those which participate and regulate key metabolic pathways to improve health, survival, growth, development, lactation and reproduction of the organisms [12]. The FAAs also hold great promise in the prevention and treatment of metabolic diseases. Arginine, cystine, leucine, methionine, tryptophan, tyrosine, aspartate, glycine and proline are classified as FAA in human nutrition [13]. Thus, considering that all the EAAs and FAAs were isolated from M. vollenhovenii and $C$. amnicola, these crustaceans can be considered to be highly nutritious. 
Table-1: Amino Acid Composition of Macrobrachium vollenhovenii and Callinectes amnicola

\begin{tabular}{|c|c|c|c|c|c|c|c|}
\hline \multirow[t]{3}{*}{ Amino Acid } & \multicolumn{7}{|c|}{ Concentration of Amino Acids ( $\mathrm{g} / 100 \mathrm{~g}$ of protein) } \\
\hline & \multicolumn{3}{|c|}{ M. vollenhovenii } & \multicolumn{2}{|c|}{ C. amnicola } & \multirow[t]{2}{*}{ Whole Prawn } & \multirow[t]{2}{*}{ Whole Crab } \\
\hline & $\begin{array}{l}\text { Whole } \\
\text { Prawn }\end{array}$ & $\begin{array}{l}\text { Prawn } \\
\text { Flesh }\end{array}$ & $\begin{array}{c}\text { Prawn } \\
\text { Exoskeleton }\end{array}$ & $\begin{array}{l}\text { Whole } \\
\text { Crab }\end{array}$ & $\begin{array}{l}\text { Crab } \\
\text { Flesh }\end{array}$ & & \\
\hline Glycine & $4.78^{a}$ & $4.32^{\mathrm{a}}$ & $4.28^{a}$ & $4.61^{\mathrm{a}}$ & $4.72^{a}$ & $4.78^{\mathrm{a}}$ & $4.61^{\mathrm{a}}$ \\
\hline Alanine & $4.25^{\mathrm{ab}}$ & $5.39 \mathrm{ac}$ & $5.41^{\mathrm{ac}}$ & $4.51^{\mathrm{a}}$ & $4.61^{a}$ & $4.25^{\mathrm{a}}$ & $4.51^{\mathrm{a}}$ \\
\hline Serine & $3.78^{a}$ & $3.76^{a}$ & $3.80^{a}$ & $3.22^{\mathrm{a}}$ & $3.31^{a}$ & $3.78^{a}$ & $3.22^{\mathrm{a}}$ \\
\hline Proline & $3.94 \mathrm{ab}$ & $3.20^{\mathrm{ab}}$ & $3.14^{\mathrm{ab}}$ & $4.94^{a}$ & $4.93^{a}$ & $3.94^{a}$ & $4.94^{a}$ \\
\hline Valine & $3.15^{b}$ & $4.08^{a b}$ & $4.85^{\mathrm{ab}}$ & $3.87^{a}$ & $3.87^{a}$ & $3.15^{a}$ & $3.87^{a}$ \\
\hline Threonine & $3.36^{a}$ & $3.88^{a}$ & $3.86^{a}$ & $3.93^{a}$ & $3.94^{a}$ & $3.36^{a}$ & $3.93^{a}$ \\
\hline Isoleucine & $2.68^{a}$ & $3.44^{b}$ & $4.44^{a}$ & $3.21^{a}$ & $3.22^{\mathrm{a}}$ & $2.68^{a}$ & $3.21^{a}$ \\
\hline Leucine & $8.80^{b}$ & $7.79^{a b}$ & $9.36^{b}$ & $6.41^{a}$ & $6.40^{a}$ & 8.80aab & $6.41^{a b}$ \\
\hline Aspartate & $8.53^{c}$ & $10.55^{b}$ & $11.65^{a}$ & $11.88^{a}$ & $12.64^{a}$ & $8.53^{\mathrm{ab}}$ & $11.88^{\mathrm{ab}}$ \\
\hline Lysine & $5.25^{b}$ & $8.16^{a}$ & $4.52^{\mathrm{b}}$ & $5.92^{\mathrm{a}}$ & $5.90^{a}$ & $5.25^{b}$ & $5.92^{\mathrm{ab}}$ \\
\hline Methionine & $1.27^{a b}$ & $2.66^{a}$ & $1.32^{\mathrm{ab}}$ & $2.06^{a}$ & $5.95^{\mathrm{ab}}$ & $1.27^{b}$ & $2.06^{b}$ \\
\hline Glutamate & $14.23^{a}$ & $16.06^{a}$ & $16.78^{a}$ & $15.41^{a}$ & $16.93^{a}$ & $14.23^{b}$ & $15.41^{b}$ \\
\hline Phenylalanine & $5.09^{a}$ & $3.90^{\mathrm{ab}}$ & $4.67^{a b}$ & $5.18^{a}$ & $5.17^{a}$ & $5.09^{a}$ & $5.18^{a}$ \\
\hline Histidine & $2.22^{\mathrm{a}}$ & $2.48^{a}$ & $2.45^{\mathrm{a}}$ & $2.16^{a}$ & $2.17^{a}$ & $2.22^{a}$ & $2.16^{a}$ \\
\hline Arginine & $5.08^{\mathrm{ab}}$ & $7.00^{b}$ & $4.89^{a b}$ & $4.63^{a}$ & $3.62^{a}$ & $5.08^{b}$ & $4.63^{b}$ \\
\hline Tyrosine & $3.67^{\mathrm{ab}}$ & $3.71^{\mathrm{ab}}$ & $2.53^{b}$ & $3.10^{\mathrm{a}}$ & $3.16^{a}$ & $3.67^{a}$ & $3.10^{a}$ \\
\hline Tryptophan & $7.55^{b}$ & $1.06^{\mathrm{ab}}$ & $1.32^{\mathrm{ab}}$ & $6.42^{\mathrm{ab}}$ & $1.11^{a}$ & $7.55^{\mathrm{a}}$ & $6.42^{a}$ \\
\hline Cystine & $1.22^{\mathrm{a}}$ & $1.37^{a}$ & $1.48^{\mathrm{a}}$ & $1.16^{\mathrm{a}}$ & $1.28^{a}$ & $1.22^{\mathrm{a}}$ & $1.16^{a}$ \\
\hline
\end{tabular}

Values with different superscript in the row are significantly different $(P<0.05)$

In both whole M. vollenhoveni and C. amnicola, glutamate recorded the highest concentration with values of $14.23 \mathrm{~g} / 100 \mathrm{~g}$ and $15.41 \mathrm{~g} / 100 \mathrm{~g}$ of protein respectively. Leucine recorded the second highest concentration $(8.80 \mathrm{~g} / 100 \mathrm{~g})$ in $M$. vollenhovenii while aspartate with $11.88 \mathrm{~g} / 100 \mathrm{~g}$ had the second highest concentration in the crab. The results from this study, in respect of the amino acids with the highest concentration, are in agreement with the reports of Ehigiator and Oterai [8], Kücükgulmez and Celik [3] and Nalan et al. [14] who reported that glutamic acid and aspartic acid were the most abundant non-essential amino acids in European green crab (Carcinus maenas).

Glutamic acid was also reported to be the most abundant free amino acid in body meat of crab [15]. Glutamate is a powerful excitatory neurotransmitter that is released by nerve cells in the brain. It is responsible for sending signals between nerve cells, and under normal conditions, it plays an important role in learning and memory [16]. Leucine is the only dietary amino acid that can stimulate muscle protein synthesis and has important therapeutic role in stress conditions like burn, trauma, and sepsis. As a dietary supplement, leucine has been found to slow the degradation of muscle tissue by increasing the synthesis of muscle proteins [17]. Aspartate stimulates a neural receptor called the NMDA receptor, which plays a role in memory and cognition. Aspartate can be used to make several other amino acids, making it useful for preventing amino acid deficiencies [18].

The most abundant amino acids in both species were glutamine, aspartate, lysine, leucine, arginine, glycine, tryptophan and phenylalanine. They constitute about $67 \%$ and $65 \%$ of the total amino acids in M. vollenhoveni and C. amnicola respectively and this agreed with results of the study by Babu et al. [19]. The amino acid content in the two species were higher than that recorded by Bassey et al. [20], Devanathan et al. [21], Sudhakar et al. [22] and Babu et al. [19].The amino acids content of M. vollenhovenii and C. amnicola were high and this can be attributed to its omnivorous feeding habit [23] and also may be due to stress conditions caused by toxicity of heavy metals on protein metabolism [24]. The high protein concentration in crustacean species may also be due to the fact that it is the main component of the contractile elements of the striated muscles [25, 26]. The high amino acids composition of these crustaceans is an indication of their high nutritive quality.

In this study, the ratio of essential amino acids (EAA) to non- essential amino acids (NEAA) was 1.25:1 in both $M$. vollenhovenii and C. amnicola. Abdel-Salam [9] reported that the ratios of EAA: NEAA in important crustaceans from Egyptian and Saudi Arabia coasts ranged from $0.70-1.12$, and the EAA: NEAA ratio in M. vollenhovenii and Tympanotonus fuscatus were 1.05 1.09 respectively [8]. The nutritive value of any animal is determined by the presence of EAA [9]. The different amino acids in flesh of crustacean species might be associated with the varying tastes as well as textural properties of meat of the crustacean species [8]. According to Sudhakar, et al. [10], glycine, alanine, serine and threonine give sweet taste, while arginine, leucine, valine, methionine, phenylalanine and histidine give bitter taste. Thus, according to Ehigiator and Oterai [8], the different amino acids might be associated with the varying tastes as well as textural properties of meat of the two species. 
Sriket et al. [27] reported that the amino acid composition of fish differ depending on a variety of factors such as the species, size, seasonal conditions and geographical location. Comparison between the amino acid content and the FAO/WHO/UNU [28] amino acid reference values showed that most of the amino acids would meet the recommended range of amino acid requirement for children and adults. The World Health Organization recommended leucine and isoleucine requirements for adults of 14 and $10 \mathrm{mg}$ amino acid/kg body weight/day respectively. For example, a $60 \mathrm{~kg}$ adult will require 840 and $600 \mathrm{mg}$ of leucine and isoleucine per day respectively. In this study, it was found that $100 \mathrm{~g}$ flesh of $M$. vollenhovenii consisted of $7.79 \mathrm{~g}$ leucine and $3.44 \mathrm{~g}$ isoleucine. Assuming an adult human consumes $50 \mathrm{~g}$ of the prawn/day; such an adult would have been supplied with the WHO-recommended daily requirements for both leucine and isoleucine. This calculation can also hold for the other amino acids in both $M$. vollenhovenii and $C$. amnicola. This is a further indication of the nutritive quality of these crustaceans.

\section{CONCLUSION}

Edible crustaceans constitute a major source of high quality animal protein for human consumption. The crustaceans, Macrobrachium vollenhovenii and Callinectes amnicola, were selected for this study on the basis of their economic importance and aquaculture potentials. This study revealed the presence of high concentration of various essential amino acids (EAA) and nonessential amino acids (NEAA) in both crustaceans, and this is an indication of the high nutritive quality of these animals. The presence of these EAA and NEAA in concentrations high enough to satisfy the WHO-recommended daily requirements for humans is a further indication of their nutritive quality. Since both $M$. vollenhovenii and $C$. amnicola are good sources of essential and non-essential amino acids, these crustaceans can be considered as better sources of protein and can serve as substitutes for other proteinous food.

\section{REFERENCES}

1. New, M.B. (2002). Farming Freshwater Prawns: A manual for the culture of the giant river prawn, (Macrobrachium rosenbergii), FAO Fisheries Technical paper, 428, 212.

2. Chindah, A.C., Tawari, C.C.B., \& Ifechukwude, K.A. (2000). The food and feeding habits of swimming crab, Callinectes amnicola (Portunidae) of the New Calabar River, Nigeria Journal Applied Science Environmental Management , 4, 51-57.

3. Kukukgulmez, A., \& Celik, M. (2008). Amino acid composition of blue crab (Callinectes sapidus) from the North Eastern Meditterranean Sea. Journal of Applied Biological Sciences 2, 39-42.

4. Suvitha.S., Eswar, A., Anbarasu, R., Ramamoorthy, K. and Sankar, G. (.2014). Proximate amino acid and fatty acid profile of selected two marine fish from Parangipettai Coast. Asian Journal of Biomedical and Pharmaceutical Sciences, 4(40), 38-42.

5. AOAC (2006). Official Methods of Analysis (18 th Edition). Association of Analytical Chemists, Gaithersburgs, MD, USA, 793.

6. Bhavan, S. Saravana, S, Radhakrishnan, S, Shanthi, R., \& Poongodi, R. (2010). Proximate composition and profiles of amino acids and fatty acids in the muscle of adult males and females of commercially viable prawn species Macrobrachium rosenbergii collected from natural culture environments. Inter. J. Biolog., 2(2), 107-119.

7. Tag El Din, H.A., Habashy, M.M., \& Sultan,H.H. (2009). Residues use of some heavy metals and hormones in fresh water prawn (Macrobracuhium rosenbergi) and marine shrimp (Penaeus semisulcatus) with reference to the nutritive value. World $\mathrm{J}$. Zoo. 4(3), 205-215.

8. Ehigiator, F.A.R., \& Oterai, E.A.(2012). Chemical Composition \& Amino Acid Profile of a Caridean Prawn (Macrobrachium vollenhovenii) from Ovia river and tropical periwinkle (Tympanonus fuscatus) from Benin river. Edo state, Nigeria. IJRRAS, 11 (1), 162-167.

9. Abdel-Salam, H.A. (2014). Amino acid composition in the muscles of male and female commercially important crustaceans from Egyptian and Saudi Arabia coasts. American Journal of Bioscience, 2(2), 70-78.

10. Sudhakar, M., Manivannan, K., \& Soundrapandian, P. (2009). Nutritive value of hard and soft shell crabs of Portunus sanguinolentus (Herbst). Int. J. Anim. Veter. Adv.., 1(2), 44-48.

11. Sankar, R. S., \& Yogamoorthi, A. (2012). Free amino acid composition in haemolymph and muscles of the ghost crab Ocypoda platytarsis. Pakistan J. Biol. Sci. 15(10), 490-495.

12. Wu, G. (2010). Functional amino acids in growth, reproduction, and health. Advances in Nutrition 1(1), 31-37.

13. Wu, G. (2013). Functional amino acids in nutrition and health, Amino Acid, 45(3): 407-411.

14. Nalan, G., Dlua, K., \& Yerlikayaa, P. ( 2003). Determination of Proximate Composition and Mineral Contents of Blue Crab (Callinectes sapidus) and Swim Crab (Portunis pelagicus) Caught off the Gulf of Antalya, Food Chem. 80, 495-498.

15. Wang, W., Wu, Z., Dai, Z., Yang, Y., Wang, J., \& Wu, G. (2013). Glycine metabolism in animals and humans: Implications for nutrition and health. Amino Acids, 45(3), 463-477.

16. McGaw, I. J., \& Reiber C.L. (2000). Integrated physiological responses to feeding in the blue crab Callinectes sapidus. Journal of Experimental Biology, 203, 359-368.

17. Bandt, J.P., \& Cynober, L. (2006): Therapeutic use of branched-chain amino acids in burns, trauma and sepsis. Journal of Nutrition 185(1), 308-313.

18. Mathews, C. K., \& van Holde, K.E. (1990). Biochemistry. The Benjamin/Cummings Publ. Co, Redwood City, CA, USA, 1299.

19. Babu, K.K., Arnadurai, D., \& Rajagopal, S. (2010). Bursa spinosa - A megastropod fit for human consumption. J. Food Science and Technology 2, 79-83.

20. Bassey, S.C.O., Eteng, M.U., Eyong, E.U., Ofem, O.E., \& Akunyoung, E.O. (2011). Comparative nutritional and biochemical evaluation of Ergeria radiate (clams) and Pomecia palludosa (gastropods). Res J Agric and Biol Sci 7, 98-104. 
21. Devanathan, K., Srinivasan, M., Periyasamy, N., \& Balakrishnan, S. (2011). Nutritional value of gastropod Babylonia spirata from Thazhanguda, Southeast Coast of India. Asian Pacific J Tropical Bio 3, 229-252.

22. Sudhakar, M., Rafa, K., Anathan, G. and Sampathkaumar, P. (2011). Compositional characteristics and nutritional quality of Podopthalamus vigil (Fabricius). .Asian Journal of Science. 4(2), 166-174.

23. Bello-Olusoji, O.A., Bankole, M., Sheu, A., \& Oyekanmi, F.B. (2006). Availability, diet composition and feeding behaviours of some palaemonidae prawns in fresh and brackish water in Nigeria. J. Biol. Sci. 6, 15-21.

24. Karat, P.S., Ghoble, L.B., Kale, R.S., \& Ghoble, B.C. (2009). Impact of TBCC on Total protein content in freshwater prawn, Macrobrachium istnensis. Middle East J Scientific Research, 4, 180-184.

25. Mona, H.M., Geasa, N.S., Sharshar, M.K., \& Morsy, M.E. (2002). Chemical composition of freshwater crayfish Erugosquilla massavensis and its nutritive values. J. aquatic. Biol. Fish, 4(1), 19-34.

26. Abdel-Salam, H.A., \& Hamdi, A.H. (2011). Biochemical compositions and heavy metals accumulation capacity of the of the marine mantis shrimp Erugosquilla massavensis. Soc. Zoo. 61, 199-214.

27. Sriket, P., Benjakul, S., Visessanguan, W., \& Kijroongrojana, K. (2007). Comparative studies on chemical composition and thermal properties of black tiger prawn (Penaeus monodon) and white prawn (Penaeus vannamei) meats. Food Chem, 103, 1199-1207.

28. FAO/WHO/UNU. (1985). Expert Consultation on Energy and protein requirements. Technical Report Series 724. World Health Organizatio, Geneva. 